\title{
The importance of sponges and mangroves in supporting fish communities on degraded coral reefs in Caribbean Panama
}

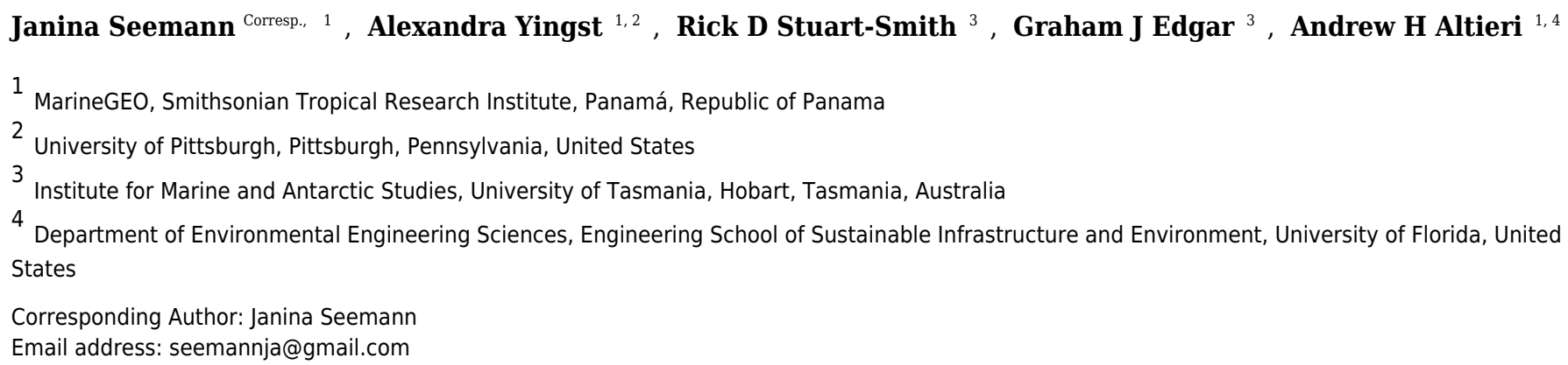

Fish communities associated with coral reefs worldwide are threatened by habitat degradation and overexploitation. We assessed coral reefs, mangrove fringes, and seagrass meadows on the Caribbean coast of Panama to explore the influences of their proximity to one another, habitat cover, and environmental characteristics in sustaining biomass, species richness and trophic structure of fish communities in a degraded tropical ecosystem. We found $94 \%$ of all fish across all habitat types were of small body size $(\leq 10 \mathrm{~cm})$, with communities dominated by fishes that usually live in habitats of low complexity, such as Pomacentridae (damselfishes) and Gobiidae (gobies). Total fish biomass was very low, with the trend of small fishes from low trophic levels overrepresented, and top predators under-represented, relative to coral reefs elsewhere in the Caribbean. For example, herbivorous fishes comprised $27 \%$ of total fish biomass in Panama relative to $10 \%$ in the wider Caribbean, and the small parrotfish Scarus iseri comprised $72 \%$ of the parrotfish biomass. We found evidence that non-coral biogenic habitats support reef-associated fish communities. In particular, the abundance of sponges on a given reef and proximity of mangroves were found to be important positive correlates of reef fish species richness, biomass, abundance and trophic structure. Our study indicates that a diverse fish community can persist on degraded coral reefs, and that the availability and arrangement within the seascape of other habitat-forming organisms, including sponges and mangroves, is critical to the maintenance of functional processes in such ecosystems. 
1 The importance of sponges and mangroves in supporting fish communities on degraded

2 coral reefs in Caribbean Panama

3 Janina Seemann ${ }^{1 *}$, Alexandra Yingst ${ }^{1,2}$, Rick D. Stuart-Smith ${ }^{3}$, Graham J. Edgar ${ }^{3}$, Andrew H.

4 Altieri $^{1,4}$

$5 \quad{ }^{1}$ MarineGEO, Smithsonian Tropical Research Institute, Panamá, Republic of Panama

$6 \quad{ }^{2}$ University of Pittsburgh, Pittsburgh, Pennsylvania, USA

$7 \quad{ }^{3}$ Institute for Marine and Antarctic Studies, University of Tasmania, Hobart, Tasmania, Australia

$8{ }^{4}$ Department of Environmental Engineering Sciences, Engineering School of Sustainable

9 Infrastructure and Environment, University of Florida, USA

10 Email: seemannja@gmail.com 


\section{Abstract}

12 Fish communities associated with coral reefs worldwide are threatened by habitat degradation

13 and overexploitation. We assessed coral reefs, mangrove fringes, and seagrass meadows on the

14 Caribbean coast of Panama to explore the influences of their proximity to one another, habitat

15 cover, and environmental characteristics in sustaining biomass, species richness and trophic

16 structure of fish communities in a degraded tropical ecosystem. We found $94 \%$ of all fish across

17 all habitat types were of small body size $(\leq 10 \mathrm{~cm})$, with communities dominated by fishes that

18 usually live in habitats of low complexity, such as Pomacentridae (damselfishes) and Gobiidae

19 (gobies). Total fish biomass was very low, with the trend of small fishes from low trophic levels

20 over-represented, and top predators under-represented, relative to coral reefs elsewhere in the

21 Caribbean. For example, herbivorous fishes comprised $27 \%$ of total fish biomass in Panama

22 relative to $10 \%$ in the wider Caribbean, and the small parrotfish Scarus iseri comprised $72 \%$ of

23 the parrotfish biomass. We found evidence that non-coral biogenic habitats support reef-

24 associated fish communities. In particular, the abundance of sponges on a given reef and

25 proximity of mangroves were found to be important positive correlates of reef fish species

26 richness, biomass, abundance and trophic structure. Our study indicates that a diverse fish

27 community can persist on degraded coral reefs, and that the availability and arrangement within

28 the seascape of other habitat-forming organisms, including sponges and mangroves, is critical to

29 the maintenance of functional processes in such ecosystems. 
30

31 Coral reef fishes are useful model communities for exploring drivers of species diversity at

32 landscape and regional scales (Galzin et al. 1994; Fabricius et al. 2005; Knowlton et al. 2010;

33 Wilson et al. 2010). They are sensitive to changes in habitat and anthropogenic impacts - a

34 particular concern given that fishes play an important role in coral reef ecosystems, and declines

35 of coral reef fishes threaten people's livelihoods and food security (Cesar 2000; Cesar et al. 2003;

36 Bellwood et al. 2004; Paddack et al. 2009). A variety of human impacts are responsible for

37 coastal degradation, including habitat destruction, eutrophication, and sedimentation (Hughes

38 1994; Jackson et al. 2001; Aronson et al. 2003). Climate change has contributed to ecosystem

39 decline through coral die-off from bleaching, hypoxia events and storms (Wilson 2006; Alvarez-

40 Filip et al. 2009; Wilson et al. 2010; Altieri et al. 2017). The consequences of these events are

41 structural collapses and habitat homogenization in coral reefs, effects which have a variety of

42 potential direct and indirect implications for resident organisms (Bell and Galzin 1984; Jackson et

43 al. 2001; Kuffner et al. 2007; Wilson et al. 2010; Alevizon and Porter 2015; Mora 2015).

44 Additional factors contributing to declining reef fish abundances are unsustainable fisheries and

45 increasing demand for fish products for a growing human population (Hodgson 1999; Jackson et

46 al. 2001; Zaneveld et al. 2016). The overexploitation and disproportionate targeting of large size

47 classes and high trophic levels affect fish population structure, growth, and reproduction, and

48 contribute to a trophic imbalance and shifts in trait composition in the reef fish community

49 (Hixon et al. 2014). This, in turn has led to further changes in habitat structure, phase shifts from

50 coral to algal communities, and decreasing ecosystem stability (Saila et al. 1993; Jennings and

51 Lock 1996; White and Jentsch 2001). 
52 Reef fish populations have also been negatively affected by the loss of coastal habitats that

53 provide important nurseries (Nagelkerken et al. 2000). The nursery-role concept suggests that

54 many reef fishes (e.g., families Lutjanidae, snappers; Serranidae, groupers; Haemulidae, grunts)

55 have life cycles that include seagrass meadows and mangroves as nursery and feeding grounds

56 (Beck et al. 2001; Nagelkerken et al. 2002; Unsworth et al. 2008; Ley 2014; Serafy et al. 2015).

57 Seagrass meadows and mangrove forests have high primary and secondary productivity relative

58 to unvegetated substrates, and support high diversity and abundances of reef fishes (Nagelkerken

59 et al. 2000; Beck et al. 2001; Mumby et al. 2004). Many fish species on coral reefs therefore

60 depend on the connectivity to, and integrity of, associated habitats.

61 Our study region, the Caribbean Sea, has experienced declining reef fish populations as a result

62 of pollution, ecosystem degradation and unsustainable reef fisheries (Hughes 1994; Gardner et al.

63 2003; Bellwood et al. 2004; Paddack et al. 2009). These problems appear particularly prominent

64 at our focal study area in Bocas del Toro on the Caribbean coast of Panama, where rapid human

65 population growth connected with agriculture (banana industry) and tourism has accelerated the

66 decline of water quality and the physical destruction of reefs, and has increased fishing pressure

67 (Guzmán and Jiménez 1992; Collin 2005; D’Croz et al. 2005; Cramer 2013; Aronson et al. 2014;

68 Seemann et al. 2014). Bocas del Toro encompasses a coastal coral reef-seagrass-mangrove

69 system in a semi-enclosed lagoon. It is composed of six major islands and the mainland that

70 surround the Almirante Bay, and includes mangroves fringing the mainland and mangrove islands

71 scattered across the bay (Collin 2005; Guzmán et al. 2005). Reefs are typically dominated by

72 corals with a high stress tolerance, including Porites furcata in shallow (1-4 m) and Agaricia spp.

73 (>3 m) in the deeper areas (Seemann 2013; Aronson et al. 2014; Seemann et al. 2014). Associated

74 seagrass meadows are dominated by Thalassia testudinum (turtlegrass). Mangrove fringes are

75 comprised of Rhizophora mangle (red mangrove). Several rivers, creeks and oceanic inlets 
76 discharge sediments and nutrients into the bay (Beulig 1999; Collin 2005). Bleaching and low

77 oxygen events occur regularly due to lagoonal characteristics including retention of warm water

78 and depletion of oxygen (Kaufmann and Thompson 2005; Seemann et al. 2014; Altieri et al.

79 2017). Bocas del Toro reefs potentially represent a model system for improving predictions

80 relevant throughout the region due to their exposure to common stressors, such as high

81 terrigenous runoff, nutrient levels, and overfishing, that are afflicting other coral reefs in the

82 Caribbean (Riegl et al. 2009; Sammarco and Strychar 2009; Leinfelder et al. 2012; Aronson et al.

83 2014).

84 This study aims to characterize the ecosystem attributes that facilitate the maintenance of

85 essential functions, biodiversity and biomass of coral reef fish communities in a degraded

86 ecosystem. Specifically, we (1) quantify the fish community at 67 sites in 5 bioregions of the

87 Caribbean to assess the status of our focal study system in Bocas del Toro along a gradient of

88 ecosystem degradation and over-fishing, (2) examine the effects of proximity of mangroves and

89 seagrass for fish communities on coral reefs, and (3) identify characteristics of coral reef habitat

90 that are positively related to biomass, abundance and structure of the fish community. Addressing

91 these objectives contributes to a better understanding of how landscape-scale features underlie

92 the resilience of degraded coastal habitats.

\section{Methods}

\section{Study system}

95 To place results within the wider regional context, we conducted fish surveys at reefs with

96 different fishery management restrictions in different Caribbean ecoregions.

97 In our focal study areas of Bocas del Toro on the Caribbean coast of Panama (Fig. 1), we also

98 conducted comprehensive surveys of fish communities, benthic surveys, and water quality 
99 measurements in adjacent seagrass and mangrove fringe areas. All data from Bocas del Toro were

100 collected from May to July 2015. Data for the other Caribbean regions were collected from 2012

101 to 2015. Research was conducted under a Scientific Permit from the Ministry of the Environment

102 Panama (MiAmbiente) and Autoridad de los Recursos Acuáticos de Panamá (ARAP) with the

103 Number: SE/APO-1-15 \& 10b.

\section{Caribbean Data Set}

105 Fish surveys. We conducted visual fish surveys using the Reef Life Survey (RLS) method 1

106 protocol (Edgar and Stuart-Smith 2014) at 67 reef sites in the following five ecoregions (Spalding

107 et al. 2007): Southern Caribbean (14 sites, Bonaire), Southwestern Caribbean (31 sites, Bocas del

108 Toro, Kuna Yala, Archipelago of San Andres), Greater Antilles (1 site, Grand Cayman), Floridian

109 (17 sites, Florida Keys) and Bahamian (4 sites, Turks and Caicos Islands). Surveys involved

110 underwater visual censuses by scuba divers at reef sites (each with 2-6 replicate transects) in

111 depths of 1 to $35 \mathrm{~m}$. Divers counted and assigned all fish species observed within binned size-

112 classes along a $50 \times 5 \mathrm{~m}$ belt transect $\left(250 \mathrm{~m}^{2}\right)$. All fishes sighted on each transect were recorded

113 on a waterproof datasheet as the diver swam along the transect at approximately $2 \mathrm{~m} \mathrm{~min}^{-1}$. We

114 identified fish species to the highest taxonomic resolution possible, and estimated body length for

115 each individual. The order of priority for recording accurately was to first ensure all species

116 observed along transects were included, then individuals of larger or rare species were accurately

117 counted, then estimates were made of abundances of common species. If an individual could not

118 be identified underwater, a photograph was taken for later identification. Abundance, size and

119 species identity were used to estimate biomass in $\mathrm{kg} \mathrm{ha}^{-1}$ using conversion factors provided by

120 Fishbase (www.fishbase.com), as described by Edgar and Stuart-Smith (2014).

\section{Bocas del Toro Data Set}


122 Fish surveys. The RLS method employed on coral reefs in five ecoregions was also applied in

123 seagrass and mangrove habitats located within $250 \mathrm{~m}$ of reef sites in Bocas del Toro. Seagrass

124 sites ranged in depth from $1 \mathrm{~m}$ to $4 \mathrm{~m}$, whereas mangrove fringe root systems had maximal depth

125 of $2 \mathrm{~m}$. Mangrove surveys were conducted amongst the mangroves prop roots below the upper

126 intertidal fringe with counts and size estimates made for all fishes in a $5 \mathrm{~m}$ wide belt within the

127 mangrove root system. Two $50 \mathrm{~m}$ transects were laid end-to-end along the mangrove fringe given

128 that side-by-side replicate transects typical of the RLS protocol could not be applied within

129 mangrove root habitats.

130 Habitat assessment. We conducted benthic surveys to characterize coral reef and seagrass bed

131 habitats. Reef and seagrass benthos were analyzed with 20 photo quadrats $\left(0.5 \mathrm{~m}^{2}\right)$, which were

132 taken every $2.5 \mathrm{~m}$ along the $50 \mathrm{~m}$ long transects at each site. Photos were analyzed via point

133 counting using the Coralnet annotation tool (coralnet.ucsd.edu). A total of 25 points were

134 randomly distributed on each photo and categorized. Substratum categories for analyses were:

135 healthy hard coral, bleached hard coral, recently-dead coral, anemones, non-calcifying corals

136 (including hexacorals and octocorals), sponges, sessile worms (tube worms, mostly polychaetes),

137 zoanthids, rubble, sand, rock, calcifying algae, seagrass and macroalgae. If sessile organisms

138 were too small for identification or obscured by dark shadows, then they were excluded from the

139 dataset. In addition, the distance between reef sites surveyed and nearest mangrove was measured

140 using GPS coordinates (table 1).

141 Water quality measurements. Water quality was assessed by quantifying temperature $\left({ }^{\circ} \mathrm{C}\right)$,

142 salinity (psu), water depth (m), total dissolved solids (TDS, $\mathrm{mg} \mathrm{L}^{-1}$ ), dissolved oxygen (mg L ${ }^{-1}$ ),

$143 \mathrm{pH}$, turbidity (FNU), chlorophyll $\left(\mu \mathrm{g} \mathrm{L}^{-1}\right)$, blue-green algae concentrations $\left(\mu \mathrm{g} \mathrm{L}^{-1}\right)$, and dissolved

144 organic matter (fDOM, RFU) with an Exo2 multiparameter sonde (YSI, Xylem brand) (Snazelle 
145 2015). The sonde was positioned $\sim 10 \mathrm{~cm}$ above the bottom in each habitat (reef, seagrass and

146 mangrove fringe). Measurements were recorded at intervals of $1-6$ min over a time period of at

147 least $30 \mathrm{~min}$ during the fish surveys, and constrained to the mid-day hours $10 \mathrm{am}-3 \mathrm{pm}$, hence

148 measurements were subject to the daily variability of weather conditions or tidal cycles.

\section{Data analyses.}

150 The Caribbean reef fish data set was used to characterize the fish community in relation to the

151 protection status of the sites. All 67 sites from the five different ecoregions were individually

152 classed by management type using the criteria of Edgar et al. (2014): NTZ (no take zones, $\mathrm{n}=27$ ),

153 RZ (restricted zones that allow some methods of fishing within a MPA, n=19) and OZ (open

154 zones where fishing is unrestricted, $n=12)$. These data were compared to data from Bocas del

155 Toro (OZ, n=9). Replicated surveys from each site were averaged.

156 Data from the fish surveys were used to calculate fish community metrics, including total

157 abundance (density), abundance of major fish families within size bins $(\leq 10 \mathrm{~cm} ;>10-20 \mathrm{~cm}$;

$158>20 \mathrm{~cm}$ ), total biomass, biomass of fishes $\leq 10 \mathrm{~cm}$, and total species richness. We also calculated

159 the mean trophic level as an abundance weighted mean of the reef fish community by multiplying

160 the trophic level of each species by their log abundance, summing these values across species

161 recorded on a transect, and dividing by the total log abundance of all fishes on the transect. The

162 classification of the trophic level $(2-5)$ for each species was based on feeding strategy:

163 herbivores and detritivores $(2-2.1)$, omnivores $(2.2-2.7)$, low-level carnivores $(2.8-3.4)$, mid-

164 level carnivores (3.5 - 3.9) and high-level carnivores (4 - 4.5) (classification and values obtained

165 from Fishbase; www.fishbase.org). We also compared preferred substrate types and resilience

166 factors of the fish species (values obtained from Fishbase), the latter estimated from population 
167 doubling time (low, medium, high). Fish community metrics were averaged within sites and

168 compared among regions for significant differences using one-way ANOVA or a Student's t-test.

169 For the Bocas del Toro dataset only, we assessed whether mangroves and seagrasses provided

170 juvenile or alternative habitats to coral reefs by comparing the abundance (log transformed) and

171 composition of fishes in the different habitat types. We assumed that higher abundances of fishes

172 amongst mangroves and seagrasses compared to reefs, and high species similarity, indicates

173 higher likelihood and magnitude of migration and exchange rates. We excluded small-bodied

174 species (maximum total length $\leq 12.5 \mathrm{~cm}$ ), which are presumably non-migratory fish species

175 (Dahlgren et al. 2006), such as Apogon townsendi (belted cardinalfish), Coryphopterus spp., and

176 Canthigaster rostrata (caribbean sharpnose-puffer). A principal component analysis (PCA) on

177 correlations (fish abundance log transformed, only fish $>12.5 \mathrm{~cm}$ ) was used to compare

178 differences in the fish communities between reefs at different distances to mangroves and

179 seagrass.

180 We also tested for correlations between environmental factors and the reef fish community

181 metrics across all sites. Environmental factors included reef cover, cover of the seagrass benthos,

182 distance to mangroves and water quality parameters. Fish metrics included species richness,

183 biomass, size structure, the abundances of individual fish species, tropic levels, preferred

184 substrate types and resilience factors. Data were characterized using a scatterplot matrix (see

185 appendix) and nonparametric Spearman's tests for pairwise correlation probabilities. For all

186 statistical analyses, fish abundance data were log-transformed to down-weight the extremely high

187 abundance of a few fish species (Edgar et al. 2014). All statistical analyses were conducted using

188 JMP Software 13.01. 
189 Results

\section{Characteristics of the fish community.}

191 We recorded a total of 77 fish species across all habitats in Bocas del Toro, of which 61 species

192 were found on coral reefs. The average mean richness per transect was $29 \pm 7$ (SD) species. This

193 value was low compared to our other Caribbean survey sites which had a mean richness per

194 transect of $52 \pm 4$ species (with a cumulative total of 196 species recorded in the whole

195 Caribbean) (Stuart-Smith et al. 2013; Edgar and Stuart-Smith 2014). Fish biomass on Bocas del

196 Toro reefs $\left(71 \pm 63 \mathrm{~kg} \mathrm{ha}^{-1}\right)$ was also lower than on other Caribbean reefs in both no-take zones

197 and MPAs with restricted fishing (ANOVA, $\mathrm{P}=0.02$ and 0.001 , respectively), although the

198 difference was not significantly lower for open zones ( $\mathrm{P}>0.05)$ (Fig. 2a). Moreover, the range of

199 total observed fish biomass in Bocas del Toro $\left(30-1350 \mathrm{~kg} \mathrm{ha}^{-1}\right)$ represents the lowest range

200 found amongst fish surveys conducted in the Caribbean, which were $140-5930 \mathrm{~kg} \mathrm{ha}^{-1}$

201 elsewhere.

202 The biomass of herbivorous, omnivorous and detrivorous fishes in Bocas del Toro (trophic level

$2032-2.7$ ) was $37 \%$ of the total biomass and $76 \%$ of all individual fishes counted (Fig. 2b).

204 Herbivores alone comprised $27 \pm 3.5 \%$ (SD) of biomass versus $10 \pm 4 \%$ across the wider

205 Caribbean. Pomacentridae (damselfishes) and Scarinae (parrotfishes) were the predominant taxa

206 in terms of biomass. Scarus iseri (striped parrotfish) contributed $72 \%$ of the parrotfish biomass.

207 High-level carnivores contributed $22 \pm 3.5 \%$ of total fish biomass, versus $31 \pm 4 \%$ elsewhere in

208 the Caribbean. Dominant high-level carnivores in Bocas del Toro were Caranx ruber (bar jack),

209 Cephalopholis cruentata (graysby), Hyplopectrus nigricans (black hamlet) and Scomberomorus

210 regalis (cero). There was a trend for fish communities in Bocas del Toro to exhibit a greater

211 proportion of total biomass comprised of herbivores, omnivores and detrivores (trophic level: 2 -

212 2.7), and a lower proportion comprised of high-level carnivores (trophic level: 4 - 4.5), relative to 
213 other Caribbean reefs, although the difference was not significantly different for either group 214 (Fig. 2b).

215 A total of $94 \%$ of all fishes observed across all habitat types (reef, seagrass, mangrove) in Bocas 216 del Toro were in the smallest size class ( $\leq 10 \mathrm{~cm}$ length). Fishes $\leq 10 \mathrm{~cm}$ represented $59 \%$ of the 217 total biomass within the reefs. The abundance of fishes within the smallest size class $(\leq 10 \mathrm{~cm})$ 218 was significantly higher in Bocas del Toro than other Caribbean reefs (ANOVA, $\mathrm{P}<0.0001$ ), 219 whereas the abundances of medium- $(>10-20 \mathrm{~cm})$ and large- $(\geq 20 \mathrm{~cm})$ sized fishes were 220 significantly lower (ANOVA, $\mathrm{P}<0.0001$ ) (Fig. 2c). This pattern was also evident when comparing

221 Bocas del Toro with other Caribbean reefs across fish families (table 2).

\section{Relationships between environmental factors and fish community composition}

223 Some environmental parameter and habitat factors were associated with the reef fish community

224 metrics in Bocas del Toro. Some environmental factors were not independent, as sponge cover

225 was negatively correlated with the distance to mangroves and also positively to chl $a\left(\mathrm{R}^{2}=0.60\right.$

226 and $\mathrm{R}^{2}=0.70$, respectively, $\mathrm{P}<0.01$ ). The other water quality parameters were not found to

227 correlate with any fish community or species metrics. Sponge cover was the strongest positive

228 correlate among all environmental parameters for species richness $\left(\mathrm{R}^{2}=0.5, \mathrm{P}<0.01\right)$, small fish

$229 \leq 10 \mathrm{~cm}$ biomass $\left(\mathrm{R}^{2}=0.85, \mathrm{P}<0.01\right)$, and trophic level of the fish community $\left(\mathrm{R}^{2}=0.89, \mathrm{P}<0.01\right)$.

230 The abundance of Abudefduf saxatilis (sergeant major) was significantly correlated with sponge

231 cover $\left(\mathrm{R}^{2}=0.62, \mathrm{p}=0.0027\right)$. Survey sites characterized by high sponge cover and low distance to

232 mangroves were characterized by fishes such as Abudefduf saxatilis (sergeant major),

233 Hypoplectrus nigricans (black hamlet), Coryphopterus personatus (masked goby) and

234 Coryphopterus glaucofraenum (bridled goby). Scarus iseri (striped parrotfish), Stegastes partitus

235 (bicolor damselfish) and Cephalopholis cruentatus (graysby) had a positive association with 
236 recently dead corals, however, the cover of dead corals was negatively correlated with the 237 abundance of most fish species.

238 Fish species richness on a given reef was positively correlated with richness values in nearby 239 mangroves $\left(\mathrm{R}^{2}=0.76, \mathrm{P}<0.05\right)$. The three reef sites with low sponge cover and without mangroves 240 in close proximity (Salt Creek, Popa, Hospital Point) showed lower biomass, abundances and 241 species richness of fishes (table 1, Fig. 3 and Fig. 4). The site without either mangroves or 242 seagrass nearby (Hospital Point) showed the lowest species richness.

243 Distance to mangroves was also identified as a factor that influenced reef fish communities (Fig. 244 5), suggesting that proximity to mangroves has a strong influence on reef fish communities, 245 likely by mangroves functioning as effective nursery grounds and as alternative complex habitats. 246 The proportion of carnivorous fishes was higher at the sites closer to the mangroves than those 247 sites that were further away (ANOVA, P<0.01, Fig. 4). However, a more detailed look at the fish 248 communities revealed that the sites at an intermediate distance from mangroves (STRI, Juan 249 Point, Coral Cay) possessed a significantly higher proportion of top-level carnivores than sites 250 that were closer or further away (Fig. 4, ANOVA, $\mathrm{P}<0.01$ ).

251 The highest abundances of all fish observed were recorded for the families Pomacentridae 252 (damselfishes) and Gobiidae (gobies) (table 2). However, Gobiidae were abundant only at sites 253 close to mangroves. Coryphopterus personatus (masked goby) dominated these sites, with 254 abundances up to 13 individuals $\mathrm{m}^{-2}$. RLS conducted elsewhere in the Caribbean (e.g., San 255 Andres Archipelago, $350 \mathrm{~km}$ distant) revealed much lower densities for the same species $(0.2$ 256 individuals $\mathrm{m}^{-2}$ ). 
257 Generally, fishes with life cycles closely associated with hard corals (Lewis 1997), such as

258 Pomacanthidae (angelfishes), were present in very low numbers on the reefs of Bocas del Toro

259 ( $<1$ per transect). Other reef fishes typically associated with hard substrates with a high

260 complexity, such as Balistidae (triggerfishes), Apogonidae (cardinalfishes), Muraenidae (moray

261 eels), Sciaenidae (drums), Pseudochromidae (dottybacks) and Serranidae (grouper), were scarce

262 within the bay $(<1$ per transect). Many fish species, including those at higher trophic levels, such

263 as Diodon hystrix (porcupinefish), Ginglymostoma cirratum (nurse shark), Gymnothorax funebris

264 (moray eel), Lutjanus jocu (dog snapper), Ocyurus chrysurus (yellowtail snapper), Pomacanthus

265 arcuatus (gray angelfish) were observed only on reefs with mangroves in close proximity $(\leq 250$

$266 \mathrm{~m}$ distance).

\section{Discussion}

268 Our surveys revealed that the fish fauna in Bocas del Toro is depauperate in species richness and

269 biomass by Caribbean standards. We found evidence that the fish community is representative of

270 a degraded and overexploited ecosystem, characterized by numerical dominance of fishes that are

271 small bodied and also typical of habitats of low complexity, such as Pomacentridae and Gobiidae,

272 with few representatives of fish families that achieve body sizes targeted by fisheries or that are

273 commonly associated with high-relief coral reefs. Nevertheless, sponge cover and proximity to

274 mangroves were found to be positively correlated with fish species richness, biomass, abundance

275 and trophic level. This pattern suggests that sponges as habitat-forming reef organisms, and

276 mangroves as nursery grounds and alternative habitats, continue to provide critical habitats for

277 the reef fish communities in a degraded ecosystem, and therefore counteract some effects of reef

278 degradation. 
279 Some fishes appeared to be an indicator species for the overall trends observed at our study site.

280 One example is the goby Coryphopterus personatus, which forms schools that hover in a

281 vulnerable position above the bottom in extremely high abundances (65-fold higher abundances

282 than in the San Andres Archipelago). Moreover, fish surveys in our Bocas del Toro study area

283 from 2002 revealed densities an order of magnitude lower at 1.2 individuals $\mathrm{m}^{-2}$ (Dominici-

284 Arosemena and Wolff 2005). We suggest that this goby is an indicator species for overfished

285 reefs that benefits from a loss of predatory fishes that historically limited their densities. Another

286 indicator species is Scarus iseri, which is ecologically important given its role as the predominant

287 herbivorous fish in Bocas del Toro (Kuempel and Altieri 2017). This species likely plays an

288 important role supporting the growth of sponges and corals by cropping competing macroalgae.

289 Third, Abudefduf saxatilis was identified as an indicator for sponge cover, which in turn is a

290 factor positively correlated to fish richness, biomass, abundance and relatively high mean

291 community trophic levels.

292 A degraded reef fish community in Bocas del Toro is evidenced by low total biomass, under-

293 representation of biomass at high trophic levels, and high abundance of small fishes, all classic

294 symptoms of over-fishing (Pauly et al. 1998; Myers and Worm 2003). Moreover, the range of

295 total observed fish biomass represents the lowest value found amongst fish surveys conducted in

296 the Caribbean. High-level carnivores and large fishes are depleted in intense fisheries (Cinner and

297 McClanahan 2006; Wilson et al. 2010), causing a skewing of the food web and community size

298 structure. As described by Wilson et al. (2010), the loss of individuals within the largest size

299 classes, which have the highest per capita reproductive output and produce the majority of

300 juveniles, impacts the recruitment of small size classes of juvenile reef fish. Accordingly, we

301 observed that small Haemulidae were rare on Bocas del Toro reefs. Exploitation thus appears to 
302 have contributed substantially to the distorted fish community patterns observed at Bocas del

303 Toro (Guzmán et al. 2005; Cramer 2013).

304 Another plausible hypothesis for the low total fish biomass and trophic shifts within the fish 305 community in Bocas del Toro relative to other Caribbean sites is the loss of hard corals (Turner et 306 al. 1999; Wilson et al. 2010). This in turn results in the loss of shelter and feeding grounds

307 (Turner et al. 1999; Alevizon and Porter 2015). This hypothesis was supported by significant 308 negative correlations between the proportions of recently-dead corals and the biomass of fishes, 309 as well as the finding that fish species that are known to associate with hard corals or hard 310 substrate were rare. Moreover, fishes known to live on habitats of low complexity (particularly 311 Pomacentridae and Gobiidae) and grazers (particularly Scaridae and Pomacentridae) occurred in 312 very high abundances (Booth and Baretta 1994; Bruggemann et al. 1994).

313 Herbivores, detritivores and omnivores were overrepresented in the Bocas del Toro fish 314 community compared to elsewhere in the Caribbean. Herbivorous species alone comprised nearly 315 a third of the total fish biomass, which could be explained by a decreased number of predators in 316 the system. Even though most herbivorous fishes were in the smallest size category $(\leq 10 \mathrm{~cm})$, 317 this group has the potential to control the growth of macroalgae and prevent algal phase shifts, 318 particularly in combination with invertebrate herbivores, such as sea urchins, which are abundant 319 in this system (Kuempel and Altieri 2017). However, if the reduction of live coral cover 320 continues, herbivorous fishes may reach their limits for grazing control (Williams and Polunin 321 2001; Williams et al. 2001). Also, the lack of redundant species within the herbivore functional 322 group is likely to result in low resilience, since a system with a single dominant herbivorous 323 species (e.g., Scarus iseri with $72 \%$ of biomass in our system) is vulnerable to stressors affecting 324 that species (Hughes 1994; White and Jentsch 2001). The reason for the dominance of one 
325 herbivore species may be attributable to the small body size of S.iseri, which matures at $\sim 65$

$326 \mathrm{~mm}$. It is therefore not a targeted fishery species, and escapes most fishing pressure (Kuempel

327 and Altieri 2017).

328 Sponges cover up to $20 \%$ of substrata, and thus provide considerable physical structure on the 329 Bocas del Toro reefs (Diaz and Rützler 2001; Loh and Pawlik 2014; Loh et al. 2015). In the 330 absence of high cover of hard corals, sponges likely play an important role in supporting richness, 331 biomass and expanded trophic levels of the depauperate fish community in our study system. We

332 found evidence for such a positive effect, with an increased abundance of reef fishes with 333 increased sponge cover. Sponges are major determinants of the rugosity and height of the reef 334 (Diaz and Rützler 2001), and thus could be an important driver for fish abundance and species 335 richness in Bocas del Toro as in other Caribbean reef systems (Gratwicke and Speight 2005). 336 Sponges also comprise an important food source for spongivorous reef fishes, such as some 337 members of Pomacentridae and Scarinae (Sammarco et al. 1987; Dunlap and Pawlik 1996; 338 Pawlik 1998; Souza et al. 2011). The pomacentrid A. saxatilis has been identified to have a 339 functional dependency on sponges through either shelter or other aspects of habitat complexity 340 that sponges provide (Gratwicke and Speight 2005).

341 Proximity to mangroves was another important positive factor associated with fish communities, 342 as the biomass and species richness of fishes were greater on coral reefs near mangroves.

343 Mangroves are widely recognized for their functions of providing nursery grounds, shelter and

344 food sources for reef fishes (Laegdsgaard and Johnson 2001; Mumby et al. 2004). Our study 345 suggests that the positive effect of mangroves as nursery and alternative adult habitats is an 346 important factor maintaining diversity and biomass of the reef fish communities, and that this 347 function remains particularly important in a system as degraded as Bocas del Toro. However, we 
348 did not find such evidence for seagrass meadows. Lowest fish species richness, biomass and

349 trophic levels were found on reefs without mangroves in close proximity, presumably because

350 many reef fish species depend on interconnectivity between habitat types (Ley 2014).

351 Our findings suggest that Bocas del Toro, Panama is a model system for the study of reef fish

352 communities that are associated with high levels of anthropogenic stress. Trends suggest that

353 stressed systems are increasingly moving to low diversity, low mean trophic level, and a size

354 distribution skewed to small body size (Pauly et al. 1998) as observed in Bocas del Toro. To

355 maintain reef fish communities, resource managers should take factors such as sponge cover and

356 proximity to other habitats, including mangroves, into consideration to prioritize protection

357 efforts. Our results suggest that reef sponges and mangroves together can maintain physical

358 structure, act as nurseries, and provide alternative habitats and thereby compensate for particular

359 functional losses during coral mortality events. Much more information is nevertheless needed on

360 the role of habitat connectivity if fisheries management is to be optimized and diversity hotspots

361 safeguarded through effective spatial management that includes marine protected areas (Linton

362 and Warner 2003; Unsworth et al. 2008).

\section{Acknowledgements}

364 We thank divers who helped with the fish surveys and fish identification or benthic surveys, 365 especially Scott Jones, Zachary Foltz, Ross Whippo, Justin Campbell, Jan Vincente and Seamus

366 Harrison. We thank the people from the Bocas Research Station team for logistical help and for

367 assistance with all aspects of the work, particularly Plinio Gondola. This is contribution 24 from

368 the Smithsonian Institutions's MarineGEO network.

\section{References}


370

371

372

373

374

375

376

377

378

379

380

381

382

383

384

385

386

387

388

389

390

391

392

393

394

395

396

397

398

399

400

401

402

403

404

405

406

407

408

409

410

411

412

413

414

415

416

417

418

Alevizon W, Porter J (2015) Coral loss and fish guild stability on a Caribbean coral reef: 19742000. Environmental Biology of Fishes 98:1035-1045

Altieri AH, Harrison SB, Seemann J, Collin R, Diaz RJ, Knowlton N (2017) Tropical dead zones and mass mortalities on coral reefs. Proceedings of the National Academy of Sciences

Alvarez-Filip L, Dulvy NK, Gill JA, Côté IM, Watkinson AR (2009) Flattening of Caribbean coral reefs: region-wide declines in architectural complexity. Proceedings of the Royal Society of London Series B-Biological Sciences 276:3019-3025

Aronson RB, Hilbun NL, Bianchi TS, Filley TR, Mckee BA (2014) Land use, water quality, and the history of coral assemblages at Bocas del Toro, Panamá. Marine Ecology Progress Series 504:159-170

Aronson RB, Bruno JF, Precht WF, Glynn PW, Harvell CD, Kaufman L, Rogers CS, Shinn EA, Valentine JF (2003) Causes of coral reef degradation. Science 302:1502-1504

Beck MW, Heck Jr KL, Able KW, Childers DL, Eggleston DB, Gillanders BM, Halpern B, Hays CG, Hoshino K, Minello TJ (2001) The identification, conservation, and management of estuarine and marine nurseries for fish and invertebrates: a better understanding of the habitats that serve as nurseries for marine species and the factors that create site-specific variability in nursery quality will improve conservation and management of these areas. Bioscience 51:633-641

Bell J, Galzin R (1984) Influence of live coral cover on coral-reef fish communities. Marine Ecology Progress Series 15:265-274

Bellwood DR, Hughes TP, Folke C, Nystrom M (2004) Confronting the coral reef crisis. Nature 429:827

Beulig A (1999) Relative influence of terrigenous vs. reef carbonate silt on turbidity and coral distribution at Bocas del Toro, Panama. International Conference on Scientific Aspects of Coral Reef Assessment, Monitoring and Restoration

Booth DJ, Beretta GA (1994) Seasonal recruitment, habitat associations and survival of pomacentrid reef fish in the US Virgin Islands. Coral Reefs 13:81-89

Bruggemann JH, Kuyper MWM, Breeman AM (1994) Comparative analysis of foraging and habitat use by the sympatric Caribbean parrotfish Scarus vetula and Sparisoma viride (Scaridae). Marine Ecology Progress Series 112:51-66

Cesar H, Burke L, Pet-Soede L (2003) The economics of worldwide coral reef degradation. Cesar environmental economics consulting (CEEC)

Cesar HS (2000) Coral reefs: their functions, threats and economic value. Collected essays on the economics of coral reefs:14-39

Cinner JE, McClanahan TR (2006) Socioeconomic factors that lead to overfishing in small-scale coral reef fisheries of Papua New Guinea. Environmental Conservation 33:73-80

Collin R (2005) Ecological monitoring and biodiversity surveys at the Smithsonian Tropical Research Institute's Bocas del Toro Research Station. Caribbean Journal of Science 41:367-373

Cramer KL (2013) History of Human Occupation and Environmental Change in Western and Central Caribbean Panama. Bulletin of Marine Science 89:955-982

D'Croz L, Del Rosario JB, Gondola P (2005) The effect of fresh water runoff on the distribution of dissolved inorganic nutrients and plankton in the Bocas del Toro Archipelago, Caribbean Panama. Caribbean Journal of Science 41:414-429

Dahlgren CP, Kellison GT, Adams AJ, Gillanders BM, Kendall MS, Layman CA, Ley JA, Nagelkerken I, Serafy JE (2006) Marine nurseries and effective juvenile habitats concepts and applications. Marine Ecology Progress Series 312:291-295

Diaz MC, Rützler K (2001) Sponges: An essential component of Caribbean coral reefs. Bulletin of Marine Science 69:535-546

Peer] reviewing PDF | (2017:06:18954:4:0:NEW 8 Feb 2018) 
419

420

421

422

423

424

425

426

427

428

429

430

431

432

433

434

435

436

437

438

439

440

441

442

443

444

445

446

447

448

449

450

451

452

453

454

455

456

457

458

459

460

461

462

463

464

465

466

Dominici-Arosemena A, Wolff M (2005) Reef fish community structure in Bocas del Toro (Caribbean, Panama): gradients in habitat complexity and exposure. Caribbean Journal of Science 41:613-637

Dunlap M, Pawlik JR (1996) Video-monitored predation by Caribbean reef fishes on an array of mangrove and reef sponges. Marine Biology 126:117-123

Edgar GJ, Stuart-Smith RD, Willis TJ, Kininmonth S, Baker SC, Banks S, Barrett NS, Becerro MA, Bernard ATF, Berkhout J, Buxton CD, Campbell SJ, Cooper AT, Davey M, Edgar SC, Forsterra G, Galvan DE, Irigoyen AJ, Kushner DJ, Moura R, Parnell PE, Shears NT, Soler G, Strain EMA, Thomson RJ (2014) Global conservation outcomes depend on marine protected areas with five key features. Nature 506:216-220

Edgar GJ, Stuart-Smith RD (2014) Systematic global assessment of reef fish communities by the Reef Life Survey program. Scientific data 1

Fabricius K, De'ath G, McCook L, Turak E, Williams DM (2005) Changes in algal, coral and fish assemblages along water quality gradients on the inshore Great Barrier Reef. Marine Pollution Bulletin 51:384-398

Galzin R, Planes S, Dufour V, Salvat B (1994) Variation in diversity of coral reef fish between French Polynesian atolls. Coral Reefs 13:175-180

Gardner TA, Côté IM, Gill JA, Grant A, Watkinson AR (2003) Long-term region-wide declines in Caribbean corals. Science 301:958-960

Granek EF, Compton JE, Phillips DL (2009) Mangrove-Exported Nutrient Incorporation by Sessile Coral Reef Invertebrates. Ecosystems 12:462-472

Gratwicke B, Speight M (2005) The relationship between fish species richness, abundance and habitat complexity in a range of shallow tropical marine habitats. Journal of Fish Biology 66:650-667

Guzmán HM, Jiménez CE (1992) Contamination of coral reefs by heavy metals along the Caribbean coast of Central America (Costa Rica and Panama). Marine Pollution Bulletin 24:554-561

Guzmán HM, Barnes PAG, Lovelock CE, Feller IC (2005) A site description of the CARICOMP mangrove, seagrass and coral reef sites in Bocas del Toro, Panama Caribbean Journal of Science 41:430-440

Hixon MA, Johnson DW, Sogard SM (2014) BOFFFFs: on the importance of conserving oldgrowth age structure in fishery populations. ICES Journal of Marine Science 71:21712185

Hodgson G (1999) A global assessment of human effects on coral reefs. Marine Pollution Bulletin 38:345-355

Hughes TP (1994) Catastrophes, phase shifts, and large-scale degradation of a Caribbean coral reef. Science 265:1547-1551

Jackson JBC, Kirby MX, Berger WH, Bjorndal KA, Botsford LW, Bourque BJ, Bradbury RH, Cooke R, Erlandson J, Estes JA, Hughes TP, Kidwell S, Lange CB, Lenihan HS, Pandolfi JM, Peterson CH, Steneck RS, Tegner MJ, Warner RR (2001) Historical Overfishing and the Recent Collapse of Coastal Ecosystems. Science 293:629-637

Jennings S, Lock JM (1996) Population and ecosystem effects of reef fishing. In: Polunin NVC, Roberts CM (eds) Reef Fisheries. Springer Netherlands, Dordrecht, pp193-218

Kaufmann KW, Thompson RC (2005) Water temperature variation and the meteorological and hydrographic environment of Bocas del Toro, Panama. Caribbean Journal of Science 41:392-413

Knowlton N, Brainard RE, Fisher R, Moews M, Plaisance L, Caley MJ (2010) Coral reef biodiversity. Life in the World's Oceans: Diversity Distribution and Abundance:65-74

Peer] reviewing PDF | (2017:06:18954:4:0:NEW 8 Feb 2018) 
467 Kuempel CD, Altieri AH (2017) The emergent role of small-bodied herbivores in pre-empting

468

469

470

471

472

473

474

475

476

477

478

479

480

481

482

483

484

485

486

487

488

489

490

491

492

493

494

495

496

497

498

499

500

501

502

503

504

505

506

507

508

509

510

511

512

513

514

515 phase shifts on degraded coral reefs. Scientific Reports 7:39670

Kuffner IB, Brock JC, Grober-Dunsmore R, Bonito VE, Hickey TD, Wright CW (2007) Relationships Between Reef Fish Communities and Remotely Sensed Rugosity Measurements in Biscayne National Park, Florida, USA. Environmental Biology of Fishes 78:71-82

Laegdsgaard P, Johnson C (2001) Why do juvenile fish utilise mangrove habitats? Journal of experimental marine biology and ecology 257:229-253

Lee S (1995) Mangrove outwelling: a review. Hydrobiologia 295:203-212

Leinfelder RR, Seemann J, Heiss GA, Struck U (2012) Could 'ecosystem atavisms' help reefs to adapt to the Anthropocene? Proceedings of the 12th International Coral Reef Symposium ICRS2012_2B_2:5

Ley JA (2014) Mangrove connectivity helps sustain coral reef fisheries under global climate change. Interrelationships Between Corals and Fisheries:171

Linton DM, Warner GF (2003) Biological indicators in the Caribbean coastal zone and their role in integrated coastal management. Ocean \& Coastal Management 46:261-276

Loh T-L, Pawlik JR (2014) Chemical defenses and resource trade-offs structure sponge communities on Caribbean coral reefs. Proceedings of the National Academy of Sciences 111:4151-4156

Loh T-L, McMurray SE, Henkel TP, Vicente J, Pawlik JR (2015) Indirect effects of overfishing on Caribbean reefs: sponges overgrow reef-building corals. PeerJ 3:e901

Mora C (2015) Ecology of Fishes on Coral Reefs. Cambridge University Press

Mumby PJ, Edwards AJ, Arias-González JE, Lindeman KC, Blackwell PG, Gall A, Gorczynska MI, Harborne AR, Pescod CL, Renken H (2004) Mangroves enhance the biomass of coral reef fish communities in the Caribbean. Nature 427:533-536

Myers RA, Worm B (2003) Rapid worldwide depletion of predatory fish communities. Nature 423:280-283

Nagelkerken I, van der Velde G, Gorissen MW, Meijer GJ, Van't Hof T, den Hartog C (2000) Importance of Mangroves, Seagrass Beds and the Shallow Coral Reef as a Nursery for Important Coral Reef Fishes, Using a Visual Census Technique. Estuarine, Coastal and Shelf Science 51:31-44

Nagelkerken I, Roberts C, Van Der Velde G, Dorenbosch M, Van Riel M, De La Moriniere EC, Nienhuis P (2002) How important are mangroves and seagrass beds for coral-reef fish? The nursery hypothesis tested on an island scale. Marine ecology progress series 244:299305

Paddack MJ, Reynolds JD, Aguilar C, Appeldoorn RS, Beets J, Burkett EW, Chittaro PM, Clarke K, Esteves R, Fonseca AC (2009) Recent region-wide declines in Caribbean reef fish abundance. Current Biology 19:590-595

Pauly D, Christensen V, Dalsgaard J, Froese R, Torres F (1998) Fishing down marine food webs. Science 279:860-863

Pawlik JR (1998) Coral reef sponges: Do predatory fishes affect their distribution? Limnology and Oceanography 43:1396-1399

Riegl B, Purkis SJ, Keck J, Rowlands GP (2009) Monitored and modeled coral population dynamics and the refuge concept. Marine Pollution Bulletin 58:24-38

Saila S, Kocic VL, McManus J (1993) Modelling the effects of destructive fishing practices on tropical coral reefs. Marine Ecology Progress Series 94:51-60

Sammarco PW, Strychar KB (2009) Effects of Climate Change/Global Warming on Coral Reefs: Adaptation/Exaptation in Corals, Evolution in Zooxanthellae, and Biogeographic Shifts. Environmental Bioindicators 4:9 - 45 
516

517

518

519

520

521

522

523

524

525

526

527

528

529

530

531

532

533

534

535

536

537

538

539

540

541

542

543

544

545

546

547

548

549

550

551

552

553

554

555

Sammarco PW, Risk MJ, Rose C (1987) Effects of grazing and damselfish territoriality on internal bioerosion of dead corals : indirect effects. Journal of Experimental Marine Biology and Ecology 112:185-199

Seemann J (2013) The use of $13 \mathrm{C}$ and $15 \mathrm{~N}$ isotope labeling techniques to assess heterotrophy of corals. Journal of Experimental Marine Biology and Ecology 442:88-95

Seemann J, Gonzalez CT, Carballo-Bolaños R, Berry K, Heiss GA, Struck U, Leinfelder RR (2014) Assessing the ecological effects of human impacts on coral reefs in Bocas del Toro, Panama. Environmental Monitoring and Assessment 186:1747-1763

Serafy JE, Shideler GS, Araújo RJ, Nagelkerken I (2015) Mangroves Enhance Reef Fish Abundance at the Caribbean Regional Scale. PloS one 10:e 0142022

Souza A, Ilarri M, Rosa I (2011) Habitat use, feeding and territorial behavior of a Brazilian endemic damselfish Stegastes rocasensis (Actinopterygii: Pomacentridae). Environmental Biology of Fishes 91:133-144

Spalding MD, Fox HE, Allen GR, Davidson N, Ferdaña ZA, Finlayson M, Halpern BS, Jorge MA, Lombana A, Lourie SA (2007) Marine ecoregions of the world: a bioregionalization of coastal and shelf areas. BioScience 57:573-583

Stuart-Smith RD, Bates AE, Lefcheck JS, Duffy JE, Baker SC, Thomson RJ, Stuart-Smith JF, Hill NA, Kininmonth SJ, Airoldi L (2013) Integrating abundance and functional traits reveals new global hotspots of fish diversity. Nature 501:539-542

Turner SJ, Thrush SF, Hewitt JE, Cummings VJ, Funnell G (1999) Fishing impacts and the degradation or loss of habitat structure. Fisheries Management and Ecology 6:401-420

Unsworth RK, Salinas De Leon P, Garrard SL, Jompa J, Smith DJ, Bell JJ (2008) High connectivity of Indo-Pacific seagrass fish assemblages with mangrove and coral reef habitats. MARINE ECOLOGY-PROGRESS SERIES- 353:213

White PS, Jentsch A (2001) The search for generality in studies of disturbance and ecosystem dynamics Progress in botany. Springer, pp399-450

Williams I, Polunin N (2001) Large-scale associations between macroalgal cover and grazer biomass on mid-depth reefs in the Caribbean. Coral reefs 19:358-366

Williams ID, Polunin NVC, Hendrick VJ (2001) Limits to grazing by herbivorous fishes and the impact of low coral cover on macroalgal abundance on a coral reef in Belize. Marine Ecology Progress Series 222:187-196

Wilson SK (2006) Multiple disturbances and the global degradation of coral reefs: are reef fishes at risk or resilient? Global change biology 12:2220-2234

Wilson SK, Fisher R, Pratchett MS, Graham NAJ, Dulvy NK, Turner RA, Cakacaka A, Polunin NVC (2010) Habitat degradation and fishing effects on the size structure of coral reef fish communities. Ecological Applications 20:442-451

Zaneveld JR, Burkepile DE, Shantz AA, Pritchard CE, McMinds R, Payet JP, Welsh R, Correa AMS, Lemoine NP, Rosales S, Fuchs C, Maynard JA, Thurber RV (2016) Overfishing and nutrient pollution interact with temperature to disrupt coral reefs down to microbial scales. Nature Communications 7:11833 
Figure 1

Sampling sites in Bocas del Toro

Three reef sites (Punta Caracol, Casa Blanca, Almirante) possess close connectivity with mangrove habitat (within $100 \mathrm{~m}$ ), three sites (STRI, Juan Point, Coral Cay) represent reef sites further away from mangroves (100 - 250 m), and three reef sites (Popa, Salt Creek, Hospital Point) are not closely connected to mangroves (> $750 \mathrm{~m}$ ). Yellow areas are reefs and green areas are mangroves islands, gray is land, white is ocean, blue is river and blue polygon is a poorly enforced MPA.

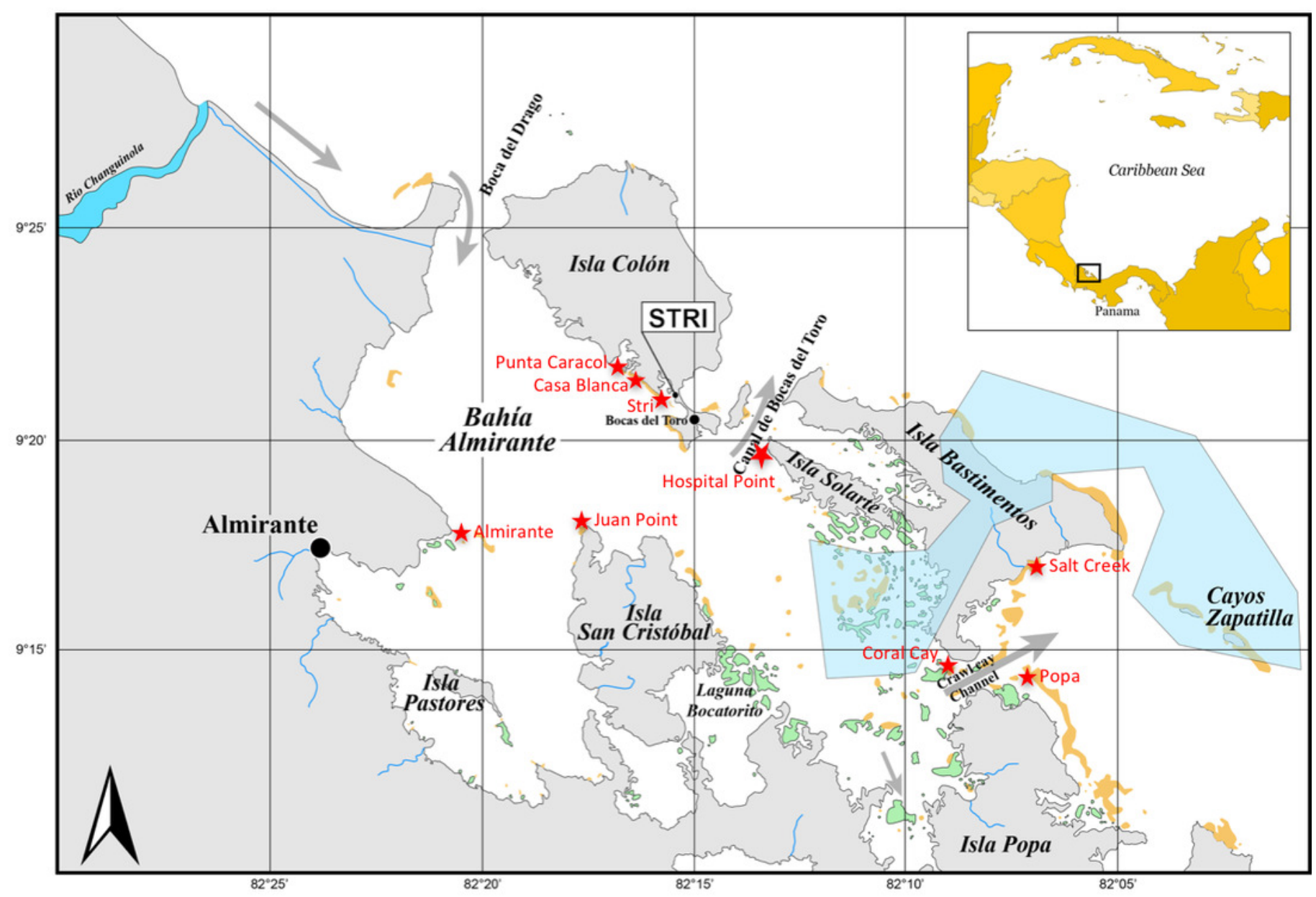




\section{Figure 2}

Biomass and composition of the fish community in the Caribbean and Bocas del Toro.

A) The comparison of the total biomass (AVR \pm SD) from RLS conducted across the Caribbean, divided in no take zones, restricted zone and open zones, and open zones in Bocas del Toro, groups with different letters are significantly different. B) Distribution of trophic guilds based on total biomass: high-level carnivores (trophic level 4 - 4.5), low and mid-level carnivore (trophic level 2.8 - 3.9), herbivores, omnivores and detrivores (trophic level 2 - 2.7). C) The abundance of fish subdivided in size classes (AVR \pm SD), which are indicative of fishing pressure (skew towards smaller body size implies fishing). Asterisk represents significant differences between size abundance data from Bocas and the Caribbean. 

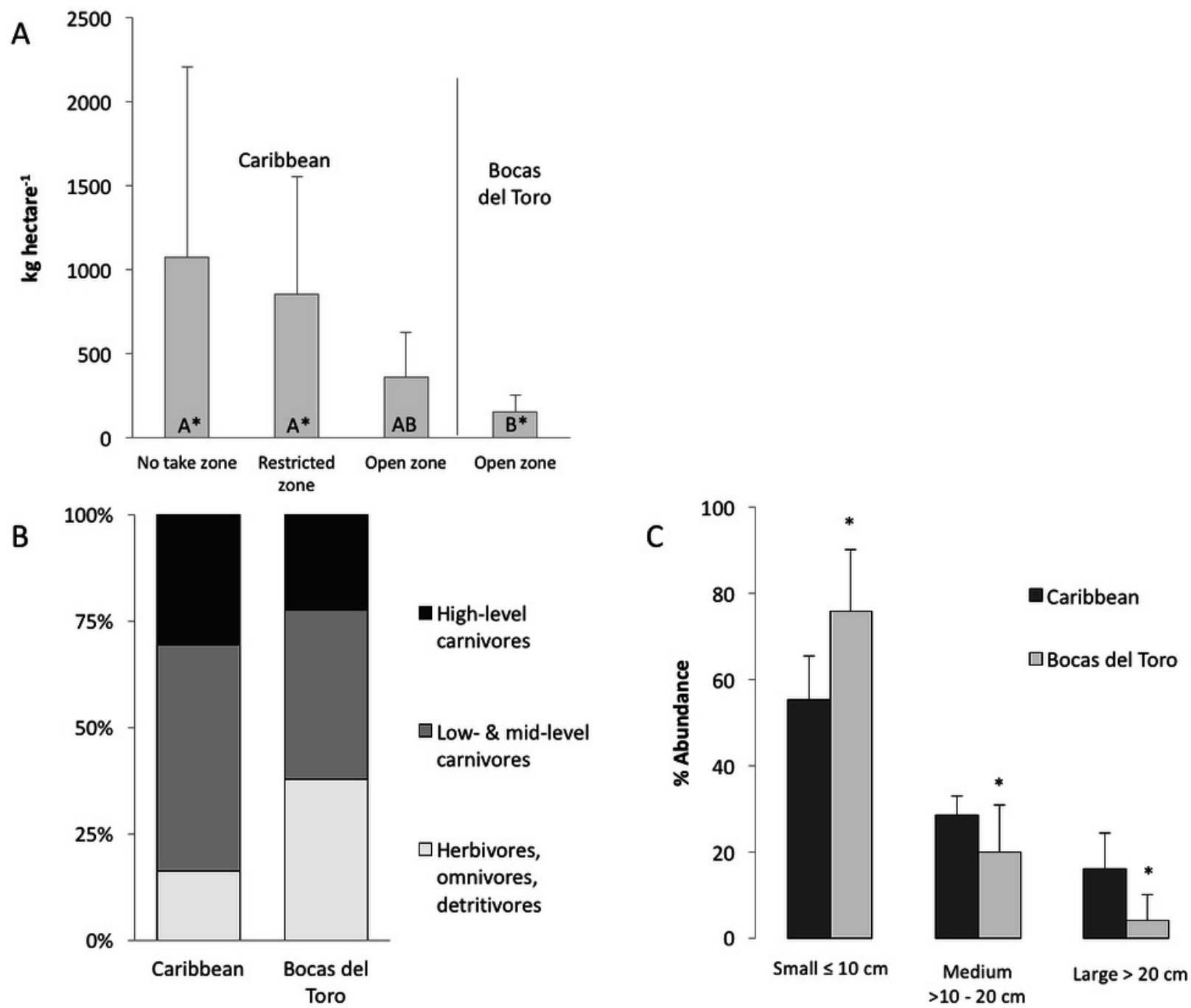


\section{Figure 3}

Biomass of trophic guilds of reef fish.

Data were pooled by sites with a similar distance to mangroves: $<100$ m (Punta Caracol, Casa Blanca, Almirante), 100 - 250 m (STRI, Juan Point, Coral Cay) and >700 m (Popa, Salt Creek, Hospital Point) (see Table 1 for detail).

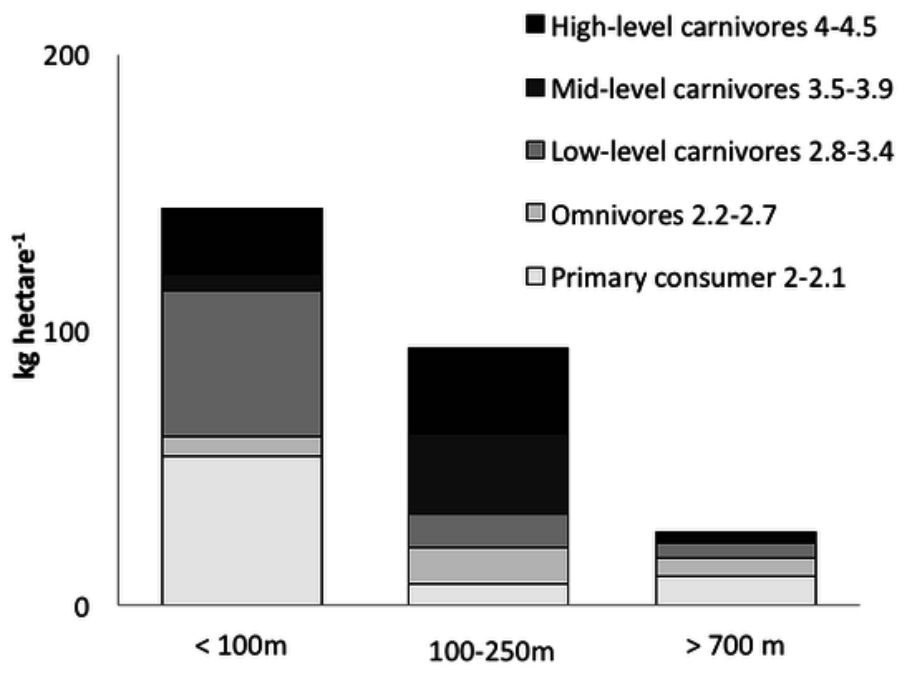

Distance to mangroves 
Figure 4

Correlation of reef fish abundance (w/o small-bodied fish) and (A) distance to mangroves or (B) sponge percent cover.
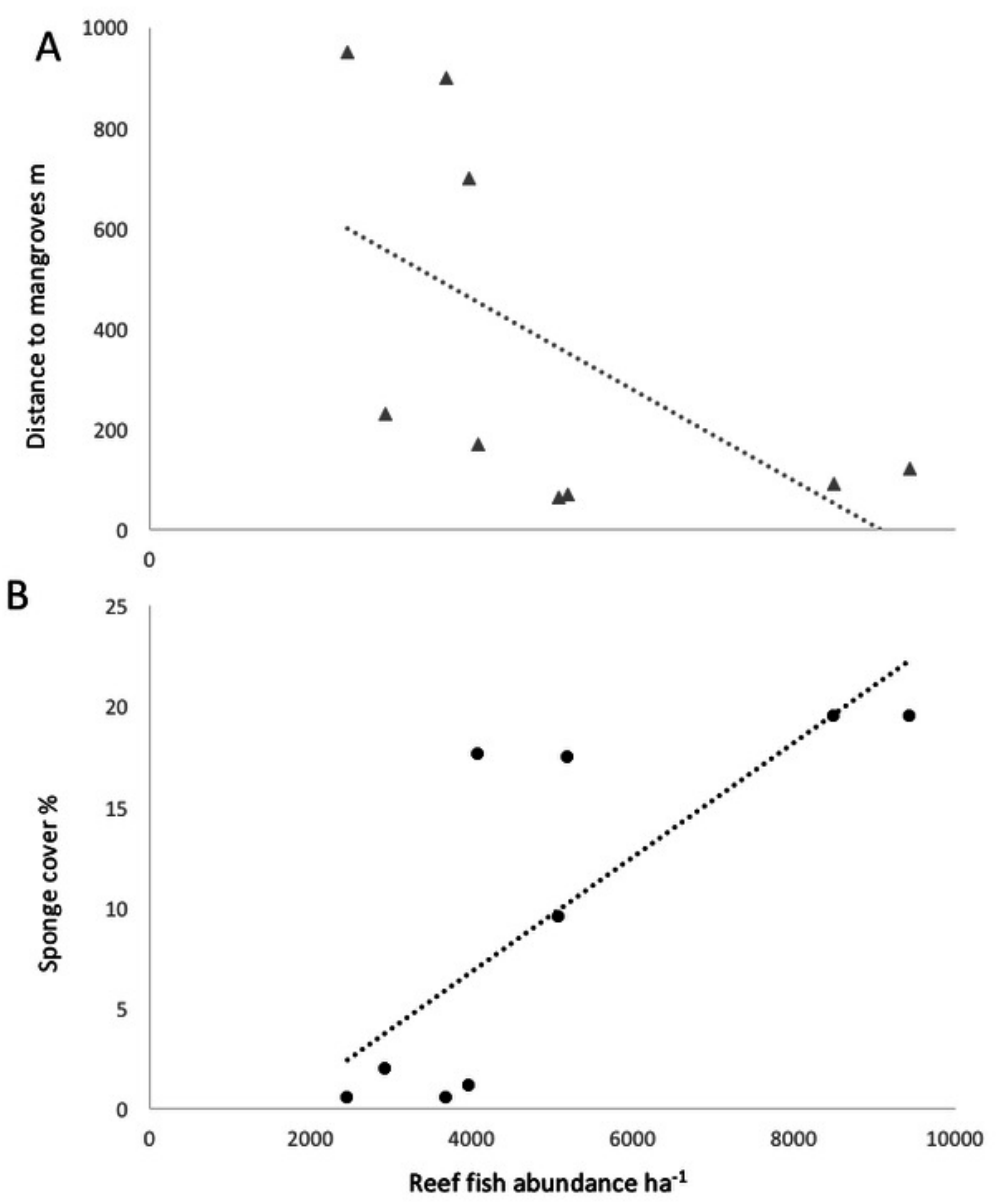


\section{Figure 5}

Principal component analyses

This PCA shows the clustering of fish communities, considering species composition and abundance ( $\log$ transformed). Small bodied fish $\leq 12.5 \mathrm{~cm}$ was excluded. Reefs $>700 \mathrm{~m}$ from mangroves cluster together as a group, separate from the reefs that are closer to mangroves. This indicates that mangrove distance has a strong influence on reef community types. The numbers refer to the site numbers in Table 1.

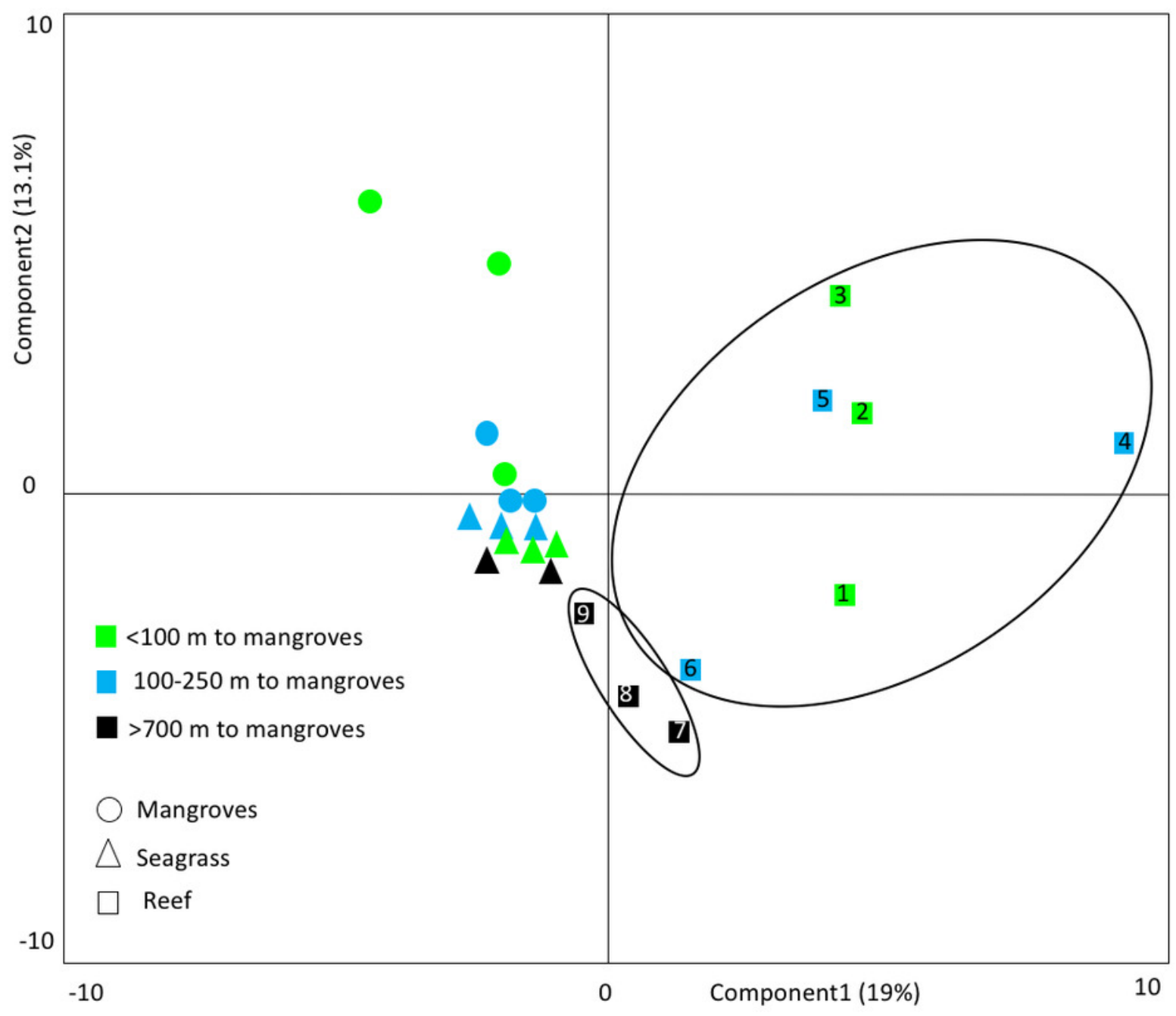




\section{Table $\mathbf{1}$ (on next page)}

Major habitat characteristics and location of monitoring sites.

Sites 7, 8 and 9 did not have mangroves in close proximity ( $\leq 250 \mathrm{~m}$ ); site 9 also did not have a seagrass meadow close to the reef, effective juvenile habitats were calculated from the fish abundance in mangroves (w/o small bodied fish) compared to reef fish abundance. 
1

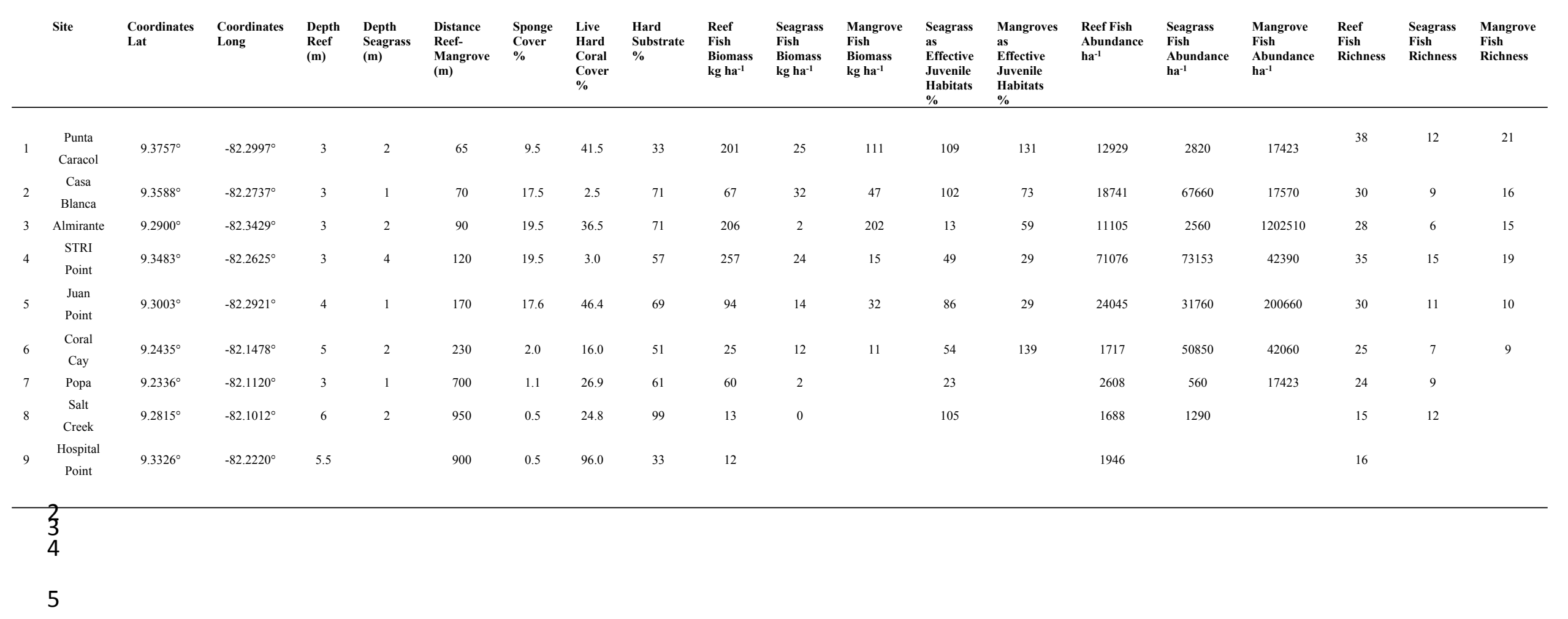




\section{Table 2 (on next page)}

Major fish families (only considering $>10$ counts ha- $^{-1}$ in average in one of the size bins). 


\begin{tabular}{|c|c|c|c|c|c|c|c|c|c|c|c|c|}
\hline & \multirow{2}{*}{\multicolumn{3}{|c|}{$\begin{array}{l}\text { Caribbean } \\
\text { Reef }\end{array}$}} & \multicolumn{9}{|c|}{ Bocas del Toro } \\
\hline & & & & Reef & Seagrass & Mangrove & Reef & Seagrass & Mangrove & Reef & Seagrass & Mangrove \\
\hline & $\leq 10 \mathrm{~cm}$ & $>10-20 \mathrm{~cm}$ & $>20 \mathrm{~cm}$ & $\leq 10 \mathrm{~cm}$ & $\leq 10 \mathrm{~cm}$ & $\leq 10 \mathrm{~cm}$ & $>10-20 \mathrm{~cm}$ & $>10-20 \mathrm{~cm}$ & $>10-20 \mathrm{~cm}$ & $>20 \mathrm{~cm}$ & $>20 \mathrm{~cm}$ & $>20 \mathrm{~cm}$ \\
\hline Acanthuridae & 317 & 351 & 127 & 113 & 127 & 120 & 233 & 0 & 20 & 0 & 0 & 0 \\
\hline Balistidae & 100 & 380 & 145 & 0 & 0 & 0 & 0 & 0 & 0 & 0 & 0 & 0 \\
\hline Carangidae & 296 & 1078 & 145 & 321 & 20 & 2593 & 330 & 80 & 100 & 40 & 0 & 0 \\
\hline Clupeidae & 11500 & 0 & 0 & 0 & 46000 & 278080 & 0 & 0 & 0 & 0 & 0 & 0 \\
\hline Ephippidae & 0 & 80 & 280 & 0 & 0 & 0 & 30 & 0 & 0 & 0 & 0 & 0 \\
\hline Gerreidae & 0 & 30 & 20 & 0 & 600 & 155 & 0 & 0 & 20 & 0 & 0 & 0 \\
\hline Gobiidae & 6239 & 0 & 0 & 18182 & 30 & 80 & 0 & 0 & 0 & 0 & 0 & 0 \\
\hline Grammatidae & 434 & 0 & 0 & 0 & 0 & 0 & 0 & 0 & 0 & 0 & 0 & 0 \\
\hline Haemulidae & 1959 & 1395 & 160 & 379 & 752 & 823 & 457 & 300 & 70 & 20 & 0 & 0 \\
\hline Holocentridae & 253 & 441 & 50 & 0 & 0 & 0 & 20 & 0 & 0 & 0 & 0 & 0 \\
\hline Inermiidae & 300 & 3444 & 0 & 0 & 0 & 0 & 0 & 0 & 0 & 0 & 0 & 0 \\
\hline Kyphosidae & 463 & 733 & 160 & 0 & 0 & 0 & 0 & 0 & 0 & 0 & 0 & 0 \\
\hline Labridae & 1749 & 659 & 96 & 254 & 568 & 580 & 252 & 180 & 80 & 0 & 0 & 0 \\
\hline Loliginidae & 0 & 240 & 0 & 0 & 0 & 0 & 0 & 0 & 0 & 0 & 0 & 0 \\
\hline Lutjanidae & 263 & 800 & 279 & 80 & 137 & 559 & 80 & 20 & 350 & 0 & 0 & 20 \\
\hline Mullidae & 245 & 429 & 229 & 50 & 20 & 0 & 20 & 0 & 0 & 0 & 0 & 0 \\
\hline Pomacentridae & 2145 & 414 & 20 & 618 & 325 & 123 & 110 & 0 & 0 & 0 & 0 & 0 \\
\hline Scaridae & 741 & 252 & 196 & 494 & 753 & 979 & 333 & 20 & 173 & 80 & 0 & 0 \\
\hline Sciaenidae & 532 & 176 & 40 & 60 & 0 & 0 & 60 & 0 & 0 & 0 & 0 & 0 \\
\hline Serranidae & 855 & 107 & 208 & 297 & 72 & 40 & 93 & 0 & 0 & 0 & 0 & 0 \\
\hline Sphyraenidae & 120 & 2100 & 180 & 0 & 0 & 40 & 0 & 20 & 40 & 0 & 0 & 100 \\
\hline Tetraodontidae & 247 & 0 & 0 & 193 & 100 & 20 & 0 & 0 & 0 & 0 & 0 & 0 \\
\hline
\end{tabular}

